\title{
Sewage cleaning by using a phase separator
}

\author{
Nikolay S. Serpokrylov ${ }^{1}$, Alla S. Smolyanichenko ${ }^{1}$, Elena V. Yakovleva ${ }^{1, *}$ \\ ${ }^{1}$ Don State Technical University, 1, Gagarin square, 344000, Rostov-on-Don, Russia
}

\begin{abstract}
This article proposes a solution to the urgent problem of treating oil-, fat-containing wastewater. A phase separator of dispersions for preliminary purification of industrial wastewater contaminated with fats is proposed, its effectiveness in the treatment of wastewater at local treatment facilities of an industrial plant for the production of sunflower oil is tested. In order to reduce the cost of acquiring reagents and increase the efficiency of purification of fat-containing wastewater, the use of carbide sludge and sodium hydroaluminate was studied. Laboratory studies conducted by the method of an active experiment.
\end{abstract}

\section{Introduction}

In the framework of import substitution, the issue of treating industrial wastewater (IWW) and waste disposal is more relevant. The deteriorating environmental situation is forcing stricter requirements for the discharge of waste and wastewater from enterprises (Table 1).

Table 1. Normative indicators of the general properties of wastewater and allowable concentrations of pollutants in wastewater that are allowed to be discharged into centralized alloy and domestic wastewater systems.

\begin{tabular}{|l|c|c|c|}
\hline \multicolumn{2}{|c|}{ Name of indicator of pollutant } & $\begin{array}{c}\text { Unit of } \\
\text { measurement }\end{array}$ & $\begin{array}{l}\text { The maximum allowable } \\
\text { value of the indicator and } \\
\text { (or) concentration in a } \\
\text { natural wastewater sample }\end{array}$ \\
\hline 1. & The reaction medium (pH) & un. & $6.0-9.0$ \\
\hline 2. & Mineralization (solid residue) & $\mathrm{mg} / \mathrm{dm}^{3}$ & 3000 \\
\hline 3. & Fats (dissolved and emulsified) & $\mathrm{mg} / \mathrm{dm}^{3}$ & 50 \\
\hline 4. & Petroleum products (dissolved and & $\mathrm{mg} / \mathrm{dm}^{3}$ & 10 \\
\hline 5. & $\begin{array}{c}\left.\text { Sulfides(S-H }{ }_{2} \mathrm{~S}+\mathrm{S}^{2-}\right) \\
\mathrm{mg} / \mathrm{dm}^{3}\end{array}$ \\
\hline 6. & Chlorine and Chloramines & $\mathrm{mg} / \mathrm{dm}^{3}$ & 1.5 \\
\hline 7. & Suspended matter & $\mathrm{mg} / \mathrm{dm}^{3}$ & 300 \\
\hline
\end{tabular}

*Corresponding author: ananas199021@yandex.ru 


\begin{tabular}{|c|c|c|c|}
\hline 8. & $\mathrm{BOD}_{5}$ & $\mathrm{mg} / \mathrm{dm}^{3}$ & 300 \\
\hline 9. & COD & $\mathrm{mg} / \mathrm{dm}^{3}$ & 500 \\
\hline 10. & Nitrogen (organic and ammonium) & $\mathrm{mg} / \mathrm{dm}^{3}$ & 50 \\
\hline 11. & Phosphorus common $\left(\mathrm{P}_{\text {tot }}\right)$ & $\mathrm{mg} / \mathrm{dm}^{3}$ & 12 \\
\hline 12. & Anionic surfactants & $\mathrm{mg} / \mathrm{dm}^{3}$ & 10 \\
\hline 13. & Phenols (amount) & $\mathrm{mg} / \mathrm{dm}^{3}$ & 0.25 \\
\hline 14. & Sulphates $\left(\mathrm{SO}_{4}{ }^{2-}\right)$ & $\mathrm{mg} / \mathrm{dm}^{3}$ & 300 \\
\hline 15. & Chlorides (Cl-) & $\mathrm{mg} / \mathrm{dm}^{3}$ & 1000 \\
\hline 16. & Aluminum(Al) & $\mathrm{mg} / \mathrm{dm}^{3}$ & 3 \\
\hline 17. & Iron $(\mathrm{Fe})$ & $\mathrm{mg} / \mathrm{dm}^{3}$ & 3 \\
\hline 18. & Manganese (Mn) & $\mathrm{mg} / \mathrm{dm}^{3}$ & 1 \\
\hline 19. & Copper $(\mathrm{Cu})$ & $\mathrm{mg} / \mathrm{dm}^{3}$ & 0.5 \\
\hline 20. & Zinc (Zn) & $\mathrm{mg} / \mathrm{dm}^{3}$ & 1.0 \\
\hline 21. & Common chrome $(\mathrm{Cr}(\mathrm{III})+\mathrm{Cr}(\mathrm{VI}))$ & $\mathrm{mg} / \mathrm{dm}^{3}$ & 0.5 \\
\hline 22. & Nickel (Ni) & $\mathrm{mg} / \mathrm{dm}^{3}$ & 0.25 \\
\hline 23. & Cadmium (Cd) & $\mathrm{mg} / \mathrm{dm}^{3}$ & 0.015 \\
\hline 24. & Lead $(\mathrm{Pb})$ & $\mathrm{mg} / \mathrm{dm}^{3}$ & 0.25 \\
\hline 25. & Mercury (Hg) & $\mathrm{mg} / \mathrm{dm}^{3}$ & 0.005 \\
\hline
\end{tabular}

To achieve these requirements, the search and development of the most effective solutions in the field of IWW purification is required [27-30].

The solution to this problem for already built local treatment facilities of enterprises (LTF), but which do not meet the requirements for the discharge of wastewater into sewage systems, is their retechnology [1, 2-6].

According to the data of the All-Russian Research Institute of Fats of the Russian Academy of Agricultural Sciences (RAAS) [7], the concentration of fats, $\mathrm{mg} / \mathrm{l}$, in the greasy wastewater $(\mathrm{GWW})$, depending on the production, are: oil extraction - 200, hydrogenation - 100, refining - 20,000, margarine - 7000, mayonnaise - 16,000, soap making - 20,000, glycerol and fatty acids - 150. In the designer's reference book [8], fat concentrations up to $2,000 \mathrm{mg} / 1$ are typical for the food industry, and therefore we consider these data to be outdated.

\section{Materials and Methods}

The studies were carried out in laboratory and pilot conditions on real wastewater of a plant for the production of vegetable oil in the Rostov region, control was carried out according to the parameters: suspended solids, fats, transparency, sediment / clarified water height, $\mathrm{pH}$. 
Analysis of the samples was carried out in an accredited laboratory.

Testing the effectiveness of reagent wastewater treatment was carried out at the LTF of an industrial plant for the production of vegetable oil in the Rostov Region. The wastewater generated in technological processes of the enterprise mainly contains fats (up to 30,000 $\mathrm{mg} / \mathrm{l}$ ) and suspended solids (up to $25,000 \mathrm{mg} / \mathrm{l}$ ) - Fig. 1.



Date of measurements

Fig. 1. Concentration of the main pollutants in the wastewater of a plant for the production of sunflower oil (average daily sample).

Note: $\mathrm{pH}$ is in the range of $6.0-8.8$.

The capacity of the treatment plant is about $7000 \mathrm{~m}^{3} /$ day. Fluctuations in consumption by the hours of the day are shown in the graph (Fig. 2)



Hours of the day

Fig. 2. Total hourly average IWW inflow over the observation period (14 months 2013-2014). 
The LTF uses the technology of physico-chemical cleaning of IWW using a pneumatic flotator, a horizontal sump with a block of thin-layer modules, a clarified water tank, vertical sumps, ruff filters and a reagent farm, which includes a solution / supply tank and a dosing system. Empirically established the residence time of the waste fluid in each structure and in pipelines, which is 120-125 minutes (Fig. 3).

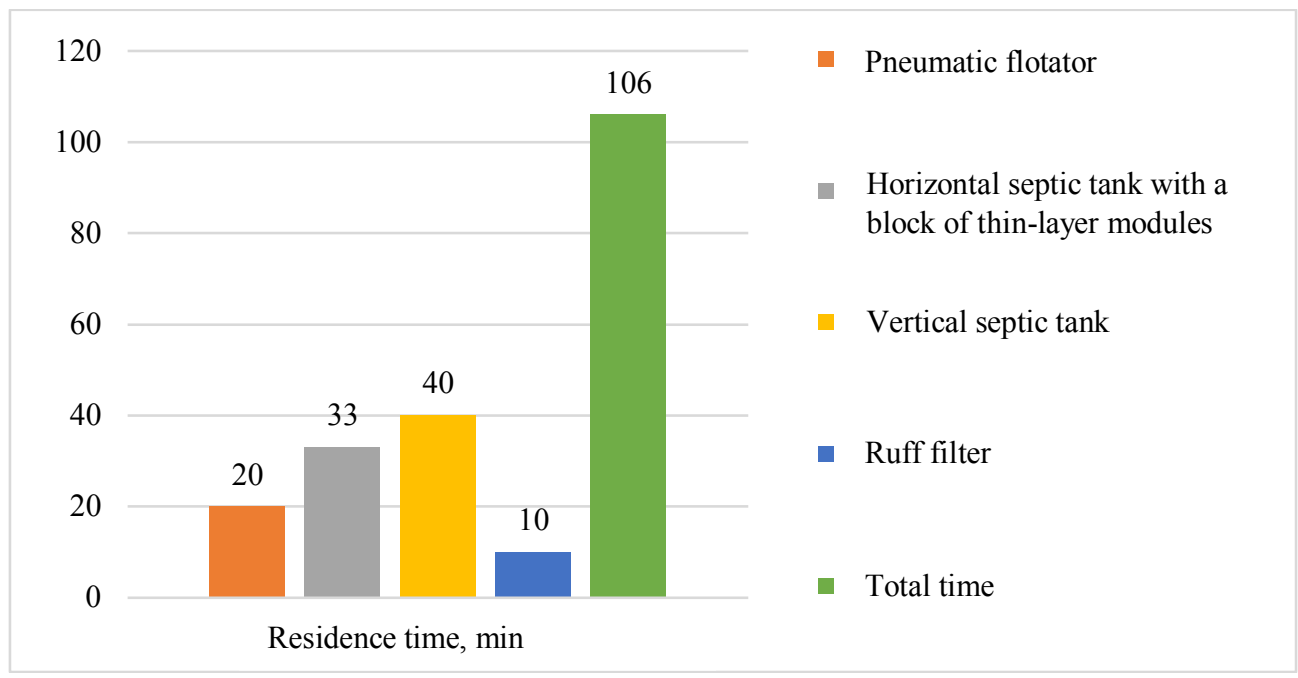

Fig. 3. The time spent by IWW on the stages of cleaning on the VOC of the enterprise.

Currently, the quality of treated wastewater at LTF does not correspond to the established temporarily permissible concentrations of pollutants (TPC) for admission to the city sewage network [9]. This leads to an increased charge for discharge of pollution, as well as (for volley discharge) poisoning of activated sludge at the city aeration station and the withdrawal of aerotanks from operating mode for 1-1.5 months.

To choose the best purification technology, it is necessary to know the nature of the fat, the composition of fatty acids, the physicochemical properties of the main components (lipids, proteins, carbohydrates) and their chemical transformations during the purification process, the nature of impurities and related substances, the phase-dispersed state of fatcontaining wastewater (FSW) and their indicators $(\mathrm{pH}$, temperature, concentration, water hardness and other factors), as well as physicochemical phenomena occurring at the phase boundary.

Machiginov V.S. a classification of fatty and related impurities in WLW has been proposed [7], which develops the well-known classification of Academician L. Kulsky A. [10]. It is based on the concept of the phase state of a substance in an aqueous medium, which, to a certain extent, is determined by its dispersion (table 2).

Table 2. The Classification of impurities FSW according to their phase-dispersed state [7].

\begin{tabular}{|c|c|c|c|c|}
\hline \multirow{3}{*}{ Indicators } & \multicolumn{4}{|c|}{ Systems } \\
\hline & \multicolumn{2}{|c|}{ heterogeneous } & \multicolumn{2}{|c|}{ homogeneous } \\
\hline & I & II & III & IV \\
\hline $\begin{array}{l}\text { The state of } \\
\text { substances } \\
\text { in water }\end{array}$ & $\begin{array}{c}\text { Suspensions } \\
\text { (suspensions and } \\
\text { emulsions), } \\
\text { insoluble in water } \\
\text { and causing } \\
\text { turbidity RAAS }\end{array}$ & $\begin{array}{l}\text { Colloidal solutions: } \\
\text { hydrophilic and } \\
\text { hydrophobic colloids } \\
\text { and macromolecular } \\
\text { substances that } \\
\text { determine the }\end{array}$ & $\begin{array}{c}\text { Molecular } \\
\text { solutions: } \\
\text { dissolved gases } \\
\text { in liquid alcohol } \\
\text { and molecular } \\
\text { soluble organic }\end{array}$ & $\begin{array}{l}\text { Ionic solutions: } \\
\text { substances that } \\
\text { dissociate in } \\
\text { water into ions }\end{array}$ \\
\hline
\end{tabular}




\begin{tabular}{|c|c|c|c|c|}
\hline & & $\begin{array}{l}\text { oxidizability and color } \\
\text { of LSW }\end{array}$ & $\begin{array}{l}\text { compounds, } \\
\text { which give the } \\
\text { liquid smell, } \\
\text { taste and color }\end{array}$ & \\
\hline $\begin{array}{l}\text { Particle } \\
\text { dispersion }\end{array}$ & $\begin{array}{c}>10^{-5}-10^{-4} \mathrm{sm} \text { or } \\
>0.1-1 \mathrm{mkm} \text { or }> \\
1000-10000 \mathrm{~A}^{\circ}\end{array}$ & $\begin{array}{c}>10^{-6}-10^{-5} \mathrm{sm} \text { or }>0.01- \\
0.1 \mathrm{mkm} \text { or }>100- \\
1000 \mathrm{~A}^{\circ}\end{array}$ & $\begin{array}{c}>10^{-7}-10^{-6} \mathrm{sm} \text { or } \\
>0.001-0.01 \\
\mathrm{mkm} \text { or }>10-100 \\
\mathrm{~A}^{\circ}\end{array}$ & $\begin{array}{c}>10^{-8}-10^{-7} \mathrm{sm} \\
\text { or }>0.0001- \\
0.001 \mathrm{mkm} \text { or } \\
>1-10 \mathrm{~A}^{\circ}\end{array}$ \\
\hline Components & $\begin{array}{l}\text { Vegetable oils and } \\
\text { animal fat } \\
\text { (triglycerins), soap } \\
\text { micelles, protein- } \\
\text { mucous complex, } \\
\text { high molecular } \\
\text { weight fatty acids, } \\
\text { clay, carbonate } \\
\text { rocks, silt, fine } \\
\text { sand, sparingly } \\
\text { soluble metal } \\
\text { hydroxides, } \\
\text { suspended organics }\end{array}$ & $\begin{array}{l}\text { Simple (waxes) and } \\
\text { complex (phospho- } \\
\text { and glycolipids, } \\
\text { proteins, } \\
\text { carbohydrates, } \\
\text { surfactants and non- } \\
\text { dissociated forms of } \\
\text { VHS staining } \\
\text { substances: gossypol, } \\
\text { sesamol, glycosides, } \\
\text { thioglycosides, } \\
\text { carotenoids, } \\
\text { chloroform), humic } \\
\text { and fulvic acids and } \\
\text { their ammonium and } \\
\text { sodium salts, soaps }\end{array}$ & $\begin{array}{l}\text { Low molecular } \\
\text { weight fatty } \\
\text { acids, glycerin, } \\
\text { alcohols, } \\
\text { hydrocarbons, } \\
\text { aldehydes, } \\
\text { ethers, vitamins, } \\
\text { pigments, } \\
\text { phenols }\end{array}$ & $\begin{array}{c}\text { Salts, acids, } \\
\text { bases, giving } \\
\text { water rigidity } \\
\text { and alkalinity, } \\
\text { phosphatides, } \\
\text { sodium salts of } \\
\text { fatty acids }\end{array}$ \\
\hline $\begin{array}{l}\text { Membrane } \\
\text { technology }\end{array}$ & Microfiltration & Ultrafiltration & Nanofiltration & $\begin{array}{l}\text { Reverse } \\
\text { osmosis }\end{array}$ \\
\hline
\end{tabular}

FSS includes all four groups of impurities and is a complex multicomponent polydisperse system containing large and small suspended solids, colloidal, molecular and ion-soluble substances. This order of groups with increasing dispersion implies a sequence of purification steps and, first of all, the removal of coarse impurities and colloidal particles. Thus, by removing the first group of particles by sedimentation or reagent-free flotation, and the second by ultrafiltration, in most cases, the purification of vital substances by the concentration of fatty substances corresponding to the normative indicators can be achieved.

This approach is implemented in a plant for pre-treatment of wastewater containing dispersed contaminants in the form of solid, liquid and gaseous phases or their combinations; a phase dispersion separator (PDS) has been proposed [11-13].

The phase separator (Fig. 4) is a rectangular tank divided by partitions into successively connected compartments: a hydrophobic filter, aeration, a settling tank with a coalescent filter at the inlet with a dedicated wastewater mixing chamber with a reagent solution and flocculation and adjustable thin-layer modules.

Note. When designing the PDS, the recommendations $[14,15]$ were taken into account regarding the residence time of water in each zone, the fluid flow rate, overall dimensions and the utilization factor of the volume of the structure, the design of the zone of thin-layer sedimentation, the angle of inclination of thin-layer modules and the material of their manufacture. 


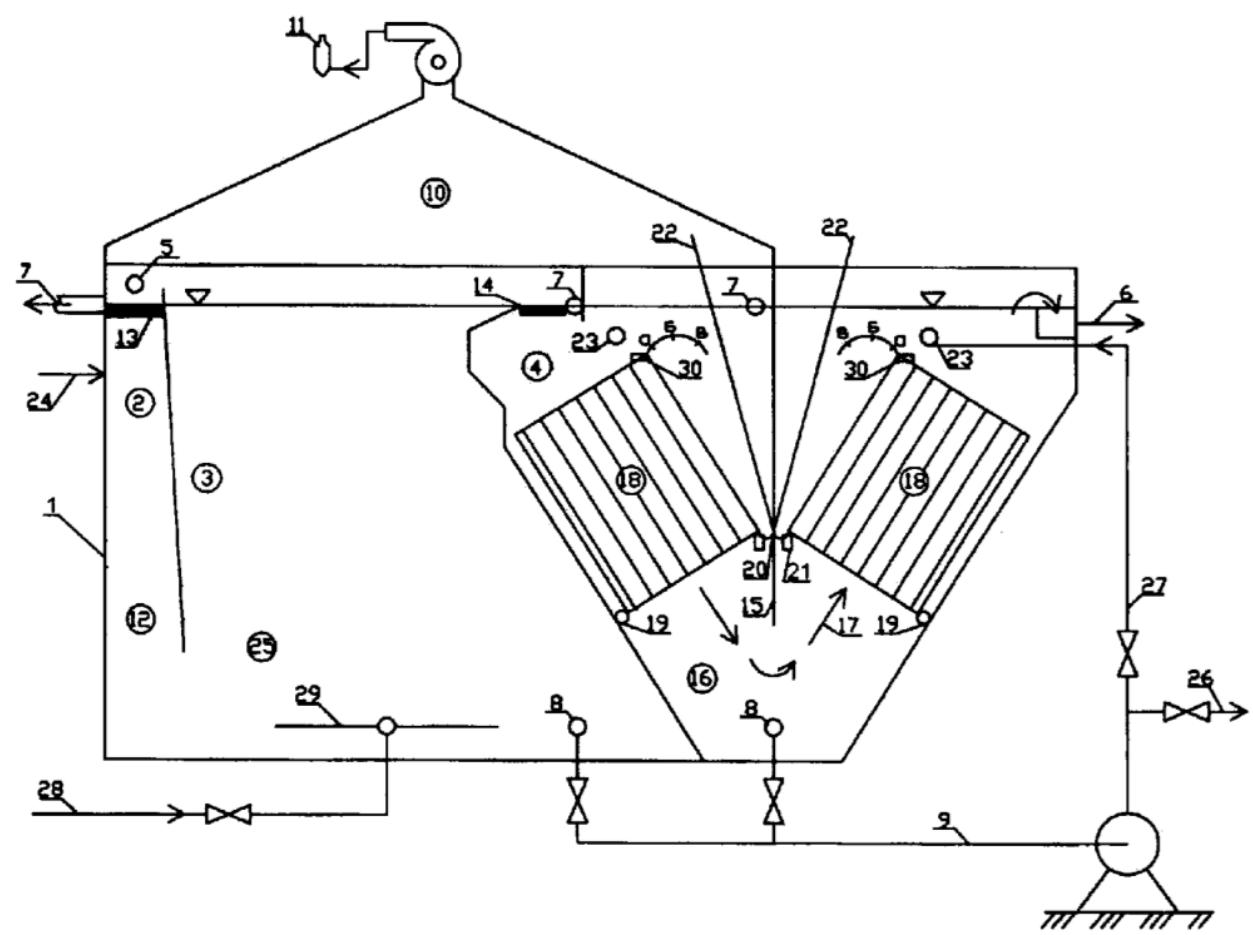

Fig. 4. Phase separator of dispersions for wastewater treatment.

Where: 1 - tank in the form of a tank with an inclined bottom, 2 - coarse treatment unit, 3 - medium treatment unit, 4 - fine treatment unit, 5 - sewage supply and distribution pipelines, 6 - sewage drainage pipeline, 7 - collection and discharge pipelines floating pollutants, 8, 9 - pipeline for collection and removal of sedimentary pollution, 10, 11 zones for the allocation, collection, removal and purification of gas impurities of wastewater, 12 - mixing chamber, 13 - coalescence filter of the coarse treatment unit, 14 coalescence filter of the medium assembly cleaning, 15 - vertical burnout not reaching the bottom Single, 16, 17 - zone downstream and upstream of wastewater, 18 - movable in the vertical plane of the thin-film modules 19 - thin hinge support modules, 20 - flexible dividing aprons, 21, 22 - openings and rods in aprons, 23 - flushing pipes for thin-layer modules, 24 - reagent supply pipe, 25 - flocculation chamber, 26 - sludge discharge pipe, 27 - flushing fluid supply pipe to thin-layer modules, 28 - air supply pipeline, 29 - fine aerator, 30 - rotary drive of thin-layer modules.

In the PDS (Fig. 4) wastewater is supplied containing contaminants in the form of suspended, emulsified and gaseous impurities (suspended solids, oils, oil products, fats, hydrogen sulfide, etc.).

The coalescent filter of the coarse treatment unit is formed from a floating layer of hydrophobic treated wastewater pollution. Emulsified (liquid) wastewater contaminants that are dispersed, passing through a layer of the same pollutants having the same surface tension, coarsen and, in the bulk, coalesce, i.e. pass from a dispersed state into a volume. The increase (excess) of the hydrophobic layer of the coalescent filter is discharged.

In the flocculation chamber, colloidal particles of a coagulant are formed, which adsorb suspended contaminants, and with the supply of air through a finely dispersed aerator, gaseous impurities are blown into the zone of allocation, collection, discharge and purification of gas wastewater impurities. Gaseous impurities released from the wastewater 
(hydrogen sulfide, mercaptans, ammonia, etc.) are discharged to the gas impurity treatment unit.

The wastewater freed from gas impurities with the formed flakes from the secondary treatment unit enters the fine treatment unit. Thin-layer modules are mounted in a countercurrent circuit: with a downward flow for the separation of dispersed contaminants with a density of less than 1 and with an upward flow for the separation of dispersed contaminants with a density of more than 1 .

Depending on the concentration and ratio of treated wastewater contaminants during commissioning, the installation determines the optimal angle of inclination of thin-layer modules using a rotary drive in position $\mathrm{a}, \mathrm{b}$ or $\mathrm{c}$.

To conduct research on the PDS operation mode, a pilot-industrial installation was made, which is a model of a phase separator of size $(\mathrm{LxBxH}=2.4 \times 0.4 \times 2.7), \mathrm{m}$. Samplers were provided that allow monitoring the quality of water treatment during each FSD compartment, in $\mathrm{t} . \mathrm{h}$. and installation height. The reagents used were Aqua-Aurat-30TM (AU) and MCAF.

The studies were carried out at the local treatment facilities (LTF) of the plant producing vegetable oils.

\section{Results}

During the treatment of fat-containing wastewater, the PDS was located in the LTF industrial building of the industrial enterprise. Wastewater was supplied from the receiving tank simultaneously to the existing grease traps and to the PDS with a flow rate of 0.55 $0.95 \mathrm{~m}^{3} / \mathrm{h}$.

The following PDS operation modes were investigated:

1. Wastewater supply without reagents, without aeration, the initial angle of inclination of thin-layer modules (TM) $60^{\circ}$.

2. The same according to p. 1 with a change in the angle of inclination of the TM to 50 и $55^{\circ}$.

3. The same according to $\mathrm{p} .1$, with aeration.

4. The same according to p.3, with a change in the angle of TM, dose AC $-60 \mathrm{mg} / \mathrm{l}$.

5. The same according to p. 4 , dose AC $-180 \mathrm{mg} / \mathrm{l}$.

6. The same according to $\mathrm{p} .1$, dose $\mathrm{MCAF}-22 \mathrm{mg} / \mathrm{l}$.

Operational control of the process was carried out visually along the "ring", and the best samples for transparency and characteristic for the regime - analytically in an accredited laboratory.

Samples for analysis were taken from the upper $(B)$ and lower $(\mathrm{H})$ through the valves (Fig. 4) of the PDS aeration zone in order to determine the height of the treated wastewater for its supply to sedimentation, as well as at the outlet of the installation. The averaged indicators of the best cleaning efficiency IWW modes are presented in table 3 and in fig. 5 .

Table 3. Indicators of preliminary treatment of fat-containing wastewater at the PDS.

\begin{tabular}{|c|c|c|c|}
\hline Cleaning Technology, Sampling Point & Fats, mg/l & $\begin{array}{c}\text { Suspended } \\
\text { substances, } \\
\text { mg/l }\end{array}$ & pH \\
\hline Mode 4, top & 179 & 516 & 7 \\
\hline Mode 4, bottom & 228 & 778 & 7 \\
\hline Mode 4, average sample & 284 & 432 & 7 \\
\hline Mode 3, exit & 107 & 312 & 7 \\
\hline
\end{tabular}




\begin{tabular}{|c|c|c|c|}
\hline Mode 3, aeration, AC, exit & 244 & 470 & 7 \\
\hline Mode 3, aeration, MCAF, exit & 198 & 214 & 7 \\
\hline
\end{tabular}

Note. Initial concentrations, mg/l: fats - 12560; suspended solids - 984, pH - 6.8.

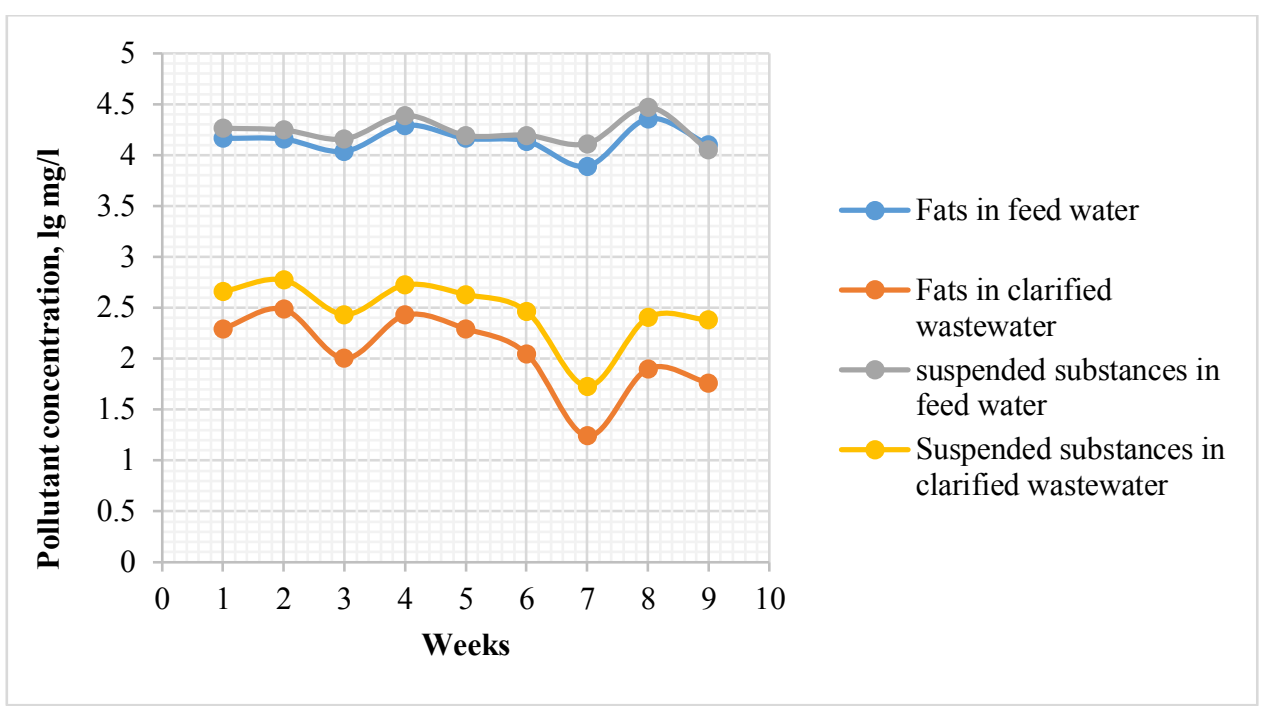

Fig. 5. Concentrations of pollutants entering and leaving wastewater from treatment facilities for the period 01.10.14-31.11.14 (averaged values over 9 weeks).

Note. Lg - logarithm of pollutant concentrations.

The research results show the high efficiency of the preliminary treatment of fatcontaining wastewater at the PDS, as well as the need for in-depth water sampling.

\section{Discussion}

During the tests, the efficiency of coalescence of fats in a hydrophobic filter at the inlet of the installation was confirmed.

According to [8], quicklime with a dose of 500-1000 mg/l, in an amount of up to 20 tons per month depending on consumption, is used as a reagent for LTF IWW of vegetable oil production enterprises, depending on consumption, which increases the production costs of the enterprise for the purchase of reagents and waste disposal. To improve the quality of treated water to the levels established by regulatory documents and to reduce costs, retechnologization of treatment plants using the physicochemical scheme of wastewater treatment has been carried out.

To replace quicklime, it was proposed to use carbide sludge, which is a large-tonnage waste from the production of acetylene.

In laboratory conditions, a test coagulation of IWW with applied and replaceable reagents was performed: carbide sludge $(\mathrm{KI})$, lime $(\mathrm{CaO})$ and sludge from the water treatment plant of the thermal power plant. When conducting trial coagulation, the conditions of mixing hydrodynamics were ensured [16].

The advantage of KI over other reagents was revealed. Thus, it was proposed to use carbide sludge to replace quicklime.

X-ray phase analysis (Fig. 6) [17] showed that carbide sludge contains phases: calcium carbonates $\left(\mathrm{CaCO}_{3}\right)$ and magnesium $\left(\mathrm{MgCO}_{3}\right)$, which allows it to be used as a reagent instead of quicklime, and its lower cost (5 times) causes a reduction in costs [18-21]. 


\section{$\mathrm{CaCO3}$}

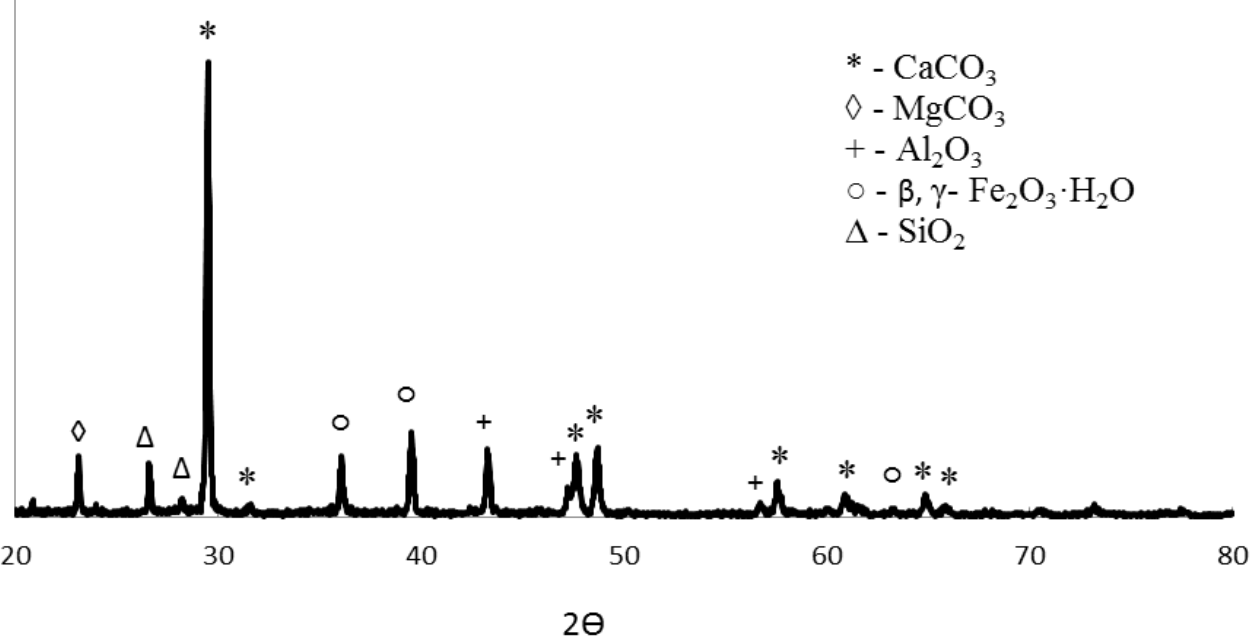

Fig. 6. X-ray of the reagent KI.

Trial coagulation was also carried out using aluminum-containing sludge, which is a large-tonnage waste that is formed during alkaline milling of aluminum structures and contains mainly sodium hydroaluminate $(70-75 \%)$, $\mathrm{pH}$ about 13 . with the main component (up to $50 \%$ ) in the form of sodium hydroaluminate (SHA) ) [7].

It was found that the best purification is achieved with a SHA dose of $10 \mathrm{~g} / 1$, while the "ring" transparency is 5-6 cm and the sludge sediment layer height is $10 \mathrm{~cm}$. In this case, the coagulation efficiency depends on the parameters of the initial waste fluid: carbonate alkalinity, $\mathrm{pH}$, concentration of contaminants and their degree of dispersion.

To optimize the reagent wastewater treatment of a sunflower oil production company, a fractional factor experiment (FFE) of type 24-1 was carried out using a reagent carbide sludge.

The studies were carried out according to the test coagulation technique with "fast" and "slow" [7.15] mixing for 30 and 120 seconds and the subsequent 30-minute sedimentation. The fat content, the volume of the layer of settled sediment, and also the value of the hydrogen index were recorded. In this case, the initial wastewater had the following indicators: $\mathrm{pH}=6.8$, sludge layer height $-0.2 \mathrm{~cm}$, fat $-2.5 \mathrm{~g} / 1$.

The optimization parameters were:

$Y_{1}$ - the effectiveness of wastewater treatment from fats:

$$
\mathrm{Y}_{1}=\left(\mathrm{C}^{\text {source }}-\mathrm{C}^{\text {pur }}\right) * 100 / \mathrm{C}^{\text {source }}, \%
$$

where $\mathrm{C}^{\text {source }}$ и $\mathrm{C}^{\text {pur }}$ - the concentration of fat in the source and treated wastewater, respectively, $\mathrm{mg} / \mathrm{l}$;

$\mathrm{Y}_{2}-\mathrm{pH}$ increase during cleaning:

$$
\mathrm{Y}_{2}=\mathrm{pH}^{\mathrm{pur}}-\mathrm{pH}^{\text {source }}
$$

where $\mathrm{pH}^{\text {source }}$ и $\mathrm{pH}^{\text {pur }}$ - the $\mathrm{pH}$ value of the source and treated wastewater, respectively.

$\mathrm{Y}_{3}$ - increase in the volume of sludge, $\mathrm{cm}^{3}$ :

$$
\mathrm{Y}_{3}=\mathrm{Sl}^{\mathrm{pur}}-\mathrm{Sl}^{\text {source }}
$$


where $\mathrm{Sl}^{\text {source }}$ и $\mathrm{Sl}^{\text {pur }}$ - sludge volume in the source and treated wastewater, respectively, $\mathrm{cm}^{3}$.

Factors and levels of variation are given in table. 4.

Table 4. Factors and levels of variation of FFE type $2^{3-1}$.

\begin{tabular}{|c|c|c|c|c|c|}
\hline \multicolumn{2}{|c|}{ Factors } & \multicolumn{2}{|c|}{ Levels of variation } & \multicolumn{2}{c|}{$\begin{array}{c}\text { Range of } \\
\text { variation }\end{array}$} \\
\cline { 3 - 6 } \multicolumn{2}{|c|}{} & - & 0 & + & \\
\hline$X_{1}$ & Dose of reagent $(\mathrm{D}), \mathrm{g} / \mathrm{l}$ & 1 & 8 & 15 & 7 \\
\hline $\mathrm{X}_{2}$ & Rapid mixing $\left(\mathrm{M}_{\mathrm{R}}\right), \mathrm{sec}$. & 30 & 75 & 120 & 45 \\
\hline $\mathrm{X}_{3}$ & Slow mixing $\left(\mathrm{M}_{\mathrm{S}}\right), \mathrm{sec}$. & 60 & 150 & 240 & 90 \\
\hline
\end{tabular}

In accordance with the strategy of an active experiment in laboratory conditions on real IWW of a plant for the production of sunflower oil, a FFE of type 23-1 with two replicates was implemented (Table 5-9) and its regression processing was carried out [10].

The obtained experimental data according to the Cochren criterion are equal (at $\mathrm{p}=$ 0.05), and the interpolation equations (4-6) of the process for calculating the efficiency of IWW purification are adequate according to the Fisher criterion.

$$
\begin{gathered}
\mathrm{Y}_{\text {calc }}^{\mathrm{F}}=67.13+22.23 \mathrm{X}_{1}+1.98 \mathrm{X}_{2}-1.98 \mathrm{X}_{3}, \% . \\
\mathrm{Y}_{\text {calc }}^{\mathrm{pH}}=1.15+0.575 \mathrm{X}_{1} \text {, un. } \mathrm{pH} \\
\mathrm{Y}_{\text {calc }}^{\mathrm{Sl}}=39.03+18.8 \mathrm{X}_{1}, \mathrm{~cm}^{3} .
\end{gathered}
$$

The transition from coded to natural factors was carried out [13], and the following equations for the efficiency of IWW purification were obtained:

- for fats

$$
\mathrm{E}_{\mathrm{F}}=35.12+0.044 \mathrm{M}_{\mathrm{R}}+0.044 \mathrm{M}_{\mathrm{S}}+3.18 \mathrm{D}, \%
$$

- for $\mathrm{pH}$

$$
\mathrm{E}_{\mathrm{pH}}=0.49+0.082 \mathrm{D}, \text { un.pH }
$$

- by volume of sludge

$$
\mathrm{E}_{\mathrm{Sl}}=17.54+2.69 \mathrm{D}, \mathrm{cm}^{3}
$$

Using the obtained equations (7-9), we plotted graphs of the dependence of the cleaning efficiency (\%) of IWW, $\mathrm{pH}$, reduction of the volume of sludge on the dose of the reagent (CI), g/l, at fast (30 s) and slow (120s) stirring (Fig. 7 a, b, c). 


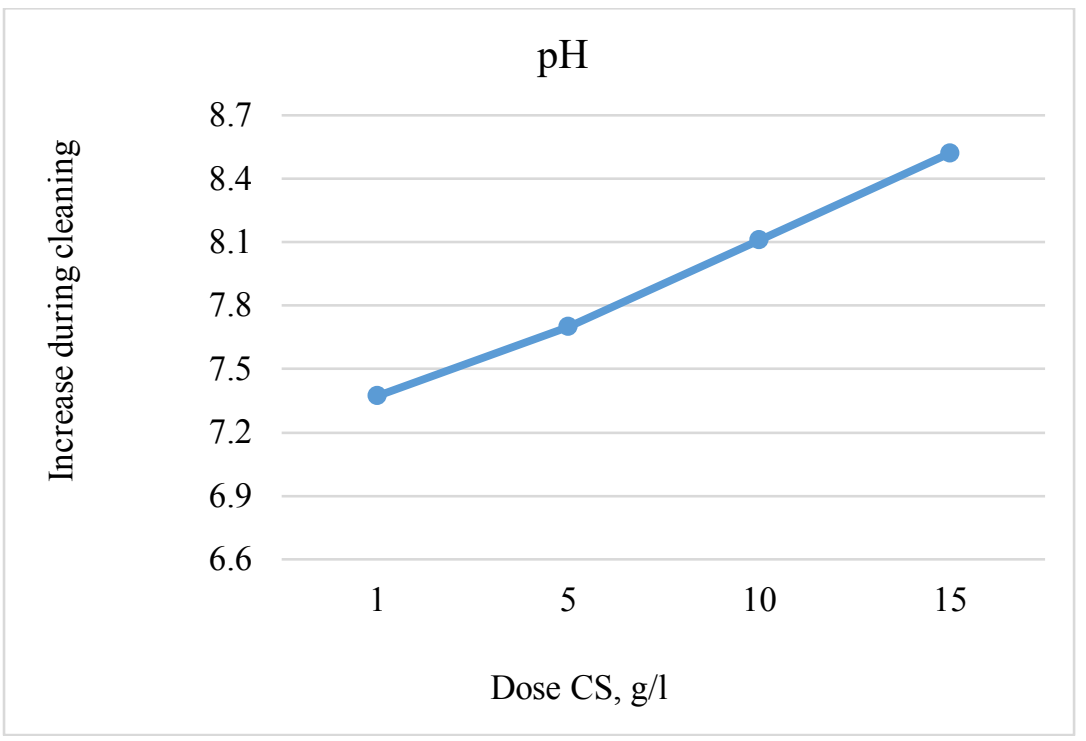

Fig. 7a. Graph of the dependence of $\mathrm{pH}$ on the dose of the reagent (CI).



Fig. 7b. Graph of the dependence of the reduction of the volume of sludge on the dose of the reagent (CI). 




Fig. 7c. Graph of the dependence of the cleaning efficiency (\%) of IWW on the dose of the reagent (CI) at fast (30 s) and slow (120s) stirring.

Note. The transparency of the wastewater treated with CS reagent, visually determined by the "ring" method, in the studies performed ranges from 9 to $9.7 \mathrm{~cm}$.

In industrial conditions, IWW carried out pilot industrial cleaning of IWW using CS and SHA as reagents (table 5).

Table 5. Indicators of pilot industrial treatment of fat-containing wastewater at the PDS using CS + SHA.

\begin{tabular}{|c|c|c|c|c|c|c|c|c|}
\hline \multirow{2}{*}{ № } & \multicolumn{2}{|c|}{$\mathrm{pH}$} & \multicolumn{2}{|c|}{ Fats, mg/l } & E, \% & \multicolumn{2}{|c|}{ Suspended substances, $\mathrm{mg} / \mathrm{l}$} & E,\% \\
\cline { 2 - 9 } & entrance & $\begin{array}{c}\text { exi } \\
\mathrm{t}\end{array}$ & $\begin{array}{c}\text { entranc } \\
\mathrm{e}\end{array}$ & exit & & entrance & exit & \\
\hline 1 & 7.9 & 7.5 & 851 & 28 & 97 & 1283 & 64 & 95 \\
\hline 2 & 8.0 & 9.1 & $15704^{*}$ & 982 & 94 & $23106^{*}$ & 4410 & 81 \\
\hline 3 & 7.4 & 8.0 & $11310^{*}$ & 211 & 98 & $163126^{*}$ & 592 & 99 \\
\hline 4 & 7.9 & 8.0 & 645 & 33 & 95 & 916 & 78 & 91 \\
\hline 5 & 8.0 & 7.1 & 873 & 204 & 77 & $1063^{*}$ & 644 & 39 \\
\hline $\begin{array}{c}\text { mediu } \\
\text { m }\end{array}$ & - & - & 5876.6 & $\begin{array}{c}291 . \\
6\end{array}$ & 95 & 37898.8 & 1157.6 & 97 \\
\hline
\end{tabular}

* The equipment was cleaned from technological mixtures

\section{Conclusions}

1. The results of pilot tests have shown the effectiveness of the use of carbide sludge (both in terms of the quality of treated water and the cost of the enterprise for the purchase of reagents) and the reliability of the equations obtained. Currently, the dose of carbide sludge in wastewater treatment plants is $18-20 \mathrm{~g} / 1$.

2. Assessing the results of the efficiency of the phase separator during the preliminary cleaning of IWW contaminated with fats, we can conclude that this apparatus can be recommended as a unit for preliminary separation of dispersed liquid and solid impurities. 


\section{References}

1. Yu.M. Meshengisser, Retekhnologizatsiya sooruzheniy ochistki stochnykh vod. (OOO «Izdatelskiy dom «Vokrug tsveta», Moscow, 2012)

2. T. Ahmed, N. Makwashi, M. Hameed, A Review of Gravity Three-Phase Separators 8(3), 143-153 (2017) ISSN: 2141-7016

3. I. Husain, M. Alkhatib, M. Jammi, M. Mirghani, Z. Zainudin, A. Hoda, Problems, Control, and Treatment of Fat, Oil, and Grease (FOG): a Review 63(8), 747-752 (2014) DOI: 10.5650/jos.ess 13182

4. D. Qian, D. Chen, N. Li, Q. Xu, H. Li, J. He, J. Lu, Journal of membrane science 554, 16-25 (2018) DOI: 10.1016/j.memsci.2017.12.084

5. P. Cisterna, Environments 4, 69 (2017) DOI: 10.3390/environments4040069

6. S. Noamani, S. Niroomand, M. Rastgar, Clean Water 20 (2019) DOI: 10.1038/s41545019-0044-z

7. V.S. Machigin, Ochistka zhirosoderzhashchikh stochnykh vod metodami ultrafiltratsii $i$ ognevogo obezvrezhivaniya: avtoref. Dis. (Saint-Petersburg, 2006)

8. V.I. Kichigin, Vodootvodyashchiye sistemy promyshlennykh predpriyatiy: uch. posobiye (Izdatelstvo ASV, Moscow, 2011)

9. E. Bayan, T. Lupeiko, M. Gorbunova, E. Tolstobrova, Russian Journal of Applied Chemistry 88(7), 1728-1732 (2015) DOI: org/10.1134/S1070427215100274

10. L.A. Kulskiy, Proyektirovaniye $i$ raschet ochistnykh sooruzheniy vodoprovodov (Budivelnik, Kiyev, 1972)

11. A. Demirbas, H. Bamufleh, G. and W. Alalayah, Treatment of contaminated wastewater 35, 883-889 (2017) DOI: 10.1080/10916466.2017.1290653

12. E. Mysara, A. Masoud, Influence of flow characteristics on the design of twophase horizontal separators 15(2) (2014)

13. J.J. Ronan, K.A. Perrotta, P.E. Rebe, Pat. 6066264, U.S. Method of Oil-Water Separation (2000)

14. V.G. Ponomarev, Ochistka proizvodstvennykh stochnykh vod ot grubodispergirovannykh primesey (Moscow, 1993)

15. B.N. Frog, Ekologo-khimicheskiye aspekty protsessov vodoochistki na predpriyatiyakh lesopromyshlennogo kompleksa (Moscow, 2002)

16. D. Butko, E. Vilson, E. Yakovleva, OALib Journal 40(4), 385-394 (2018) DOI: $10.1051 /$ matecconf $/ 201710607003$

17. R. Wongnoi, W. Songkasiri, Ch. Phalakornkule, OALib Journal 79(2), 199-207 (2007) DOI: $10.2175 / 106143006 X 111790$

18. A. Smolyanichenko, Ah. Khalil, OALib Journal 698 (2019) DOI:10.1088/1757899X/698/2/022072

19. G. Bru, P. Klimov, A. Smolyanichenko, OALib Journal 931, 966-969 (2018) DOI: 10.4028/www.scientific.net/MSF.931.974

20. Ah. Khalil, A. Smolyanichenko, E. Vilson, E. Shchutskaya, E. Tsurikova, OALib Journal 1, 212-218 (2019) DOI: 10.2991/isees-19.2019.42

21. A. Yasar, N. Ahmad, M. Chaudhry, Aa. Ali Khan, OALib Journal 19(5), 553-558 (2007) DOI: 10.1016/S1001-0742(07)60092-8 